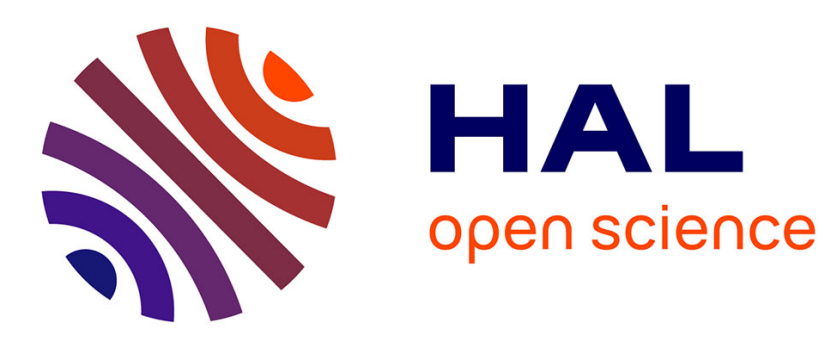

\title{
Rights transfers in Madagascar biodiversity policies: achievements and significance
}

\author{
Martine Antona, Estelle Motte Bienabe, Jean Michel Salles, Géraldine
} Péchard, Sigrid Aubert, Rivo Ratsimbarison

\section{To cite this version:}

Martine Antona, Estelle Motte Bienabe, Jean Michel Salles, Géraldine Péchard, Sigrid Aubert, et al.. Rights transfers in Madagascar biodiversity policies: achievements and significance. Environment and Development Economics, 2004, 9, pp.825-847. 10.1017/S1355770X04001640 . cirad-00843309

\section{HAL Id: cirad-00843309 http://hal.cirad.fr/cirad-00843309}

Submitted on 11 Jul 2013

HAL is a multi-disciplinary open access archive for the deposit and dissemination of scientific research documents, whether they are published or not. The documents may come from teaching and research institutions in France or abroad, or from public or private research centers.
L'archive ouverte pluridisciplinaire HAL, est destinée au dépôt et à la diffusion de documents scientifiques de niveau recherche, publiés ou non, émanant des établissements d'enseignement et de recherche français ou étrangers, des laboratoires publics ou privés. 


\title{
Rights transfers in Madagascar biodiversity policies: achievements and significance
}

\author{
MARTINE ANTONA \\ Cirad-Tera, Montpellier, France.
}

ESTELLE MOTTE BIÉNABE*, JEAN-MICHEL SALLES,
AND GÉRALDINE PÉCHARD $\dagger$
Lameta, UMR CNRS-INRA-University of Montpellier, France.

SIGRID AUBERT

Cirad-Tera, La Réunion, France.

RIVO RATSIMBARISON

Head of the GELOSE Department, Madagascar.

\begin{abstract}
Decentralization and people's participation have been key features of government environmental policy since the 1990s. In Madagascar, the policy of Secured Local Management of Natural Resources, known as the GELOSE act, has created a framework for the transfer of rights from central government to local communities. This article analyses the practical implementation of this policy by focusing on the nature of the rights transferred and on the nature of the contracts and incentives developed. The Aghion and Tirole model for allocation of formal and real authority in an organization is used to shed light on the contractual definition process and on the trade-offs between giving responsibilities to local communities and losing control over natural resources management. It is shown that a congruence of interests between the parties is crucial for effective delegation of authority to local communities and that this congruence may emerge in relation to the transfer of exclusion rights.
\end{abstract}

* Corresponding author. CIRAD TERA TA 60/15, 73, av. Jean François Breton, 34398 Montpellier cedex 5, bienabe@cirad.fr

$\dagger$ In memory of Géraldine Péchard.

This article was written following a one-week workshop held in Saint Denis, La Réunion, in October 2001, on the various insights that could be obtained with regard to the GELOSE contracting policy, from the viewpoints of economics, law and anthropology, in which all the authors took part. It greatly benefited from the contributions to this workshop made by Philippe Karpe, law researcher at CIRAD, and Serge Razafiarison, Ph.D. student in anthropology and consultant at the GEMA\&C. This research was supported by the European Union (EU) funded project BIOECON (BIOdiversity and Economics for CONservation). An early version of this paper was presented, in the BIOECON workshop on 'Propertyrelated mechanisms for biodiversity conservation' held in Rome on 30-31 May 2002 (www.bioecon.ucl.ac.uk). 


\section{Introduction}

Since the 1990s, decentralization and people's participation in management have emerged as key trends in government environmental policy in developing countries. The role of local populations in sustainable management of natural resources has been more fully recognized and the shifting of natural resource management from central to local government is usually part of a broader decentralization process (Agrawal and Ostrom, 2001; Ribot, 1999). A considerable body of academic and policy literature has been developed on these paradigms, and theoretical models have been built to guide the decentralization of government policy and devolution processes (Oates, 1972; Smith, 1985; Ostrom et al., 1993; Gerard-Varet, 1994; Crémer et al., 1996; Agrawal and Ribot, 1999). A major assumption well studied in the literature relates biodiversity loss to institutional failures, such as ill-defined property rights (Hanna and Munasinghe, 1995; Sedjo, 1995; Schmid, 1995). Recent resource management literature focuses on the idea that natural resources, as a source of biodiversity and a basis for local development, could benefit from the delegation of central government authority (Cardenas, 2000). One of the main issues is to state to whom natural resource management should be decentralized: grassroots communities or local governments (Larson, 2002).

In Madagascar, in the middle of the last decade, a contractual policy, known as GELOSE, ${ }^{1}$ was designed to transfer management of natural resources from central government to rural communities. It was implemented in response to two problems facing biodiversity conservation policy. Human settlement had been increasing in the protected areas set up by the first National Environmental Action Plans (NAEP) since the end of the 1980s (Weber, 1995; Bertrand and Weber, 1995). No biodiversity management competencies were devolved upon local political structures, reflecting a lack of awareness on the part of central administration about customary local multiple uses management (Weber, 1995; Bertrand and Razafindrabé, 1997). Authorization to use renewable natural resources within protected forested areas and their adjacent zones was delivered exclusively by the Forestry Administration. The state's inability to effectively supervise and control access to these protected areas thus led to a situation of informal multi-governance of biodiversity and of de facto open access to natural resources in protected areas, and hence to critical degradation of natural resources (Weber, 2000; Hufty and Muttenzer, 2002).

It is well known that Madagascar possesses abundant biological resources, with a large number of endemic species and a wide range of ecosystems. In recent years, the risk of biodiversity loss has been highlighted by scientists and taken up by international agencies and conservation NGOs. The decrease in forest cover was assessed over a range of 1,000 to $2,000 \mathrm{~km}^{2}$ per year (Ganzhorn et al., 2001) and the total protected area is of $15,574 \mathrm{~km}^{2}$. While primarily protection oriented, the actions of the government and of external funding agencies have been progressively influenced by an awareness of the need to link biodiversity protection

${ }^{1}$ GELOSE stands for 'Gestion Locale Sécurisée' i.e. 'Secured local management of natural resources', including biodiversity outside the protected areas. 
with development (Razafindrabe and Thompson, 1994). The two national conferences of Antsirabe held in 1993 and Mahajanga held in 1994 stated that this link must be achieved by transferring natural resources property rights (see the Antsirabe declaration in Bertrand, 1995 and the Mahajanga declaration in Weber 1995).

To address this situation, the GELOSE policy aims to promote the conservation and sustainable use of natural resources (GELOSE Act 96-025). Its basic rationale can be roughly described as a transfer of the state's de jure management right over certain renewable natural resources to local communities which formerly exerted a de facto management right over these resources based on customary rules. The local community must be organized in a way that offers scope for definition of management rules that will be effectively followed by its members, and that are in accordance with the central government's objectives.

However, what is really at stake in such policies remains partly unclear. Two levels of questions have to be addressed. What is the precise nature of the rights transferred through GELOSE contracts? And how can the GELOSE contracts be characterized? The central concern is to understand more precisely the interests of each party in these contracts. The Aghion and Tirole (1997) model of allocation of formal and real authority in an organization is used to shed light on the contractual definition process and the trade-offs between giving responsibilities to local communities and losing control over natural resources management.

In section 2, the main features and results of the Aghion and Tirole model are presented. In section 3, the institutional and economic features of the GELOSE policy are analysed. The stages of the contracting process are then described and initial achievements in terms of signed and planned contracts are presented. Then in section 4, the GELOSE policy is analysed through the Aghion and Tirole model with a view to shedding light on the major determinants of rights delegation from the government to local communities. Section 5 examines the co-ordination issues that may arise within each party due to their collective nature, along with the precise nature of the transferred rights and of the contracts.

\section{A rationale for delegating authority: the Aghion and Tirole model}

As stated by Agrawal and Ostrom (2001), a major issue relating to decentralization policy is the question of why central governments attempt decentralization and the nature of the property rights devolved by governments to local actors. Using the Schlager and Ostrom (1992) framework, we intend to determine what is really at stake with the delegation of rights and how the state stands to gain by relinquishing its control and rights over natural resources management. Hence, we are interested in the likelihood and conditions of successful delegation of rights through GELOSE policy, given the interests of each stakeholder.

Theoretical models have been built that give insight into the key mechanisms at stake with the implementation of natural resources management policies as part of a decentralization process. In a decentralized system, resource allocation should be more efficient because it is suited to local conditions and the lower information costs should 
favour policy implementation (Gerard-Varet, 1994). Oates (1972) shows that decentralization can increase government responsiveness by enabling public actions to adapt to local preferences. Besides having better knowledge of local situations, local decision makers can be held more accountable for their action (Ostrom, Schroeder, and Wynne, 1993). Downward accountability is also stressed as a key factor of the effectiveness of decentralization by Agrawal and Ribot (1999).

The goals of decentralization largely coincide with the need for effective natural resources management. One of the most striking features of natural resources management under central authority is its lack of information and control over the state of the resources and their actual level of exploitation. At the heart of the GELOSE devolution process is the active search for information, as will be developed in sections 3 and 4 . To address this issue and draw some lessons from industrial organization (Crémer et al., 1996), a model developed by Aghion and Tirole (1997) is used to analyse the interactions between the granting of authority ${ }^{2}$ through delegation and the acquisition of information and then the elements that may lead to this delegation. The question is how to determine who has the right to decide which project to implement. Though primarily focused on organization in a business context, it can be extended to the institutional framework for the management of natural resources. It could then be formulated in terms of who should take decisions about how to select natural resources management rules and what determines this mode of organization.

\subsection{The major features of the model}

The theoretical framework is that of the incomplete contract theory (Grossman and Hart, 1986). The complete outcomes of the possible scenarios resulting from different choices of project implementation, or of resource management rules in our case, cannot be totally predicted ex ante. Consequently, the sharing of costs and benefits cannot be fully specified prior to contract definition. The decisions involved are too complex for their outcomes to be specified completely in an initial contract. As stated by Aghion and Tirole, the formal authority and the power to decide and to exercise control ${ }^{3}$ over the use of an asset is given to a member of an organization by the ownership of this asset. Authority may also result from a formal or informal contract, which may then modify the prior structure of property rights over the asset. If the contract does not specify who is to decide in a particular case, this right belongs to the owner of the asset over which the decision is taken. ${ }^{4}$ Real authority is given to a member, who may or may not have the formal authority, when this member finally takes the decision.

${ }^{2}$ Simon (1947) defined authority as the 'right to select actions affecting part or the whole of an organization'.

3 '...virtually define ownership as the power to exercise control' (Grossman and Hart, 1986).

4 'We assume that the owner of each asset has the right to control that asset in the case of a missing provision' (Grossman and Hart, 1986). 
The first step of the model is the allocation of authority between the principal and the agent and, hence, the definition of the mode of organization, i.e. integration or delegation. In integration, the principal is able to overrule the decision taken by the agent. In delegation, the agent's decision takes precedence over the principal's decision. What makes the allocation of decision rights important is that the principal and the agent do not have the same order of preferences for the possible projects. A measure of the difference between the principal's and the agent's preferences is given by two exogenous parameters of congruence, which reflect each agent's expectation about the benefits he would enjoy if the other agent's preferred project was chosen (see model in appendix 1). In a second step, based on these statements, each contracting party chooses how much to learn about the projects. Then, the party which does not have formal authority transmits part of the information he has acquired to the other party. The latter, if he has enough information, decides which project to develop. When he cannot make an informed choice, he is assumed to be better off accepting the project chosen by the other party rather than choosing a project arbitrarily.

The allocation of authority will partly determine the effort made by each party to acquire information, given that this authority enables them to decide which project will be developed and then to receive maximum possible benefit from it.

\subsection{The results of the model}

Aghion and Tirole show that two main benefits arise from the delegation of formal authority. These are firstly an increase in the agent's initiative or incentive to acquire information (and hence a reduction of the principal's overload). When given the authority to decide, the agent's decision will not be overruled by the principal. The agent is thus motivated to learn more about the projects so as to make an informed choice and to implement his preferred project. Secondly, delegation facilitates the agent's participation in the contractual relationship when the issue matters relatively more to the agent than to the principal. These results come at the cost of a loss of control over the principal's choice between the projects.

The principal will delegate formal authority to the agent when the latter has better access to information and when their objectives are not too different. Hence, delegation will be favoured by closer congruence between the preferences of the principal and those of the agent. Whenever the principal benefits greatly from undertaking a project directly, formal delegation is less likely to occur. On the contrary, it is favoured by the agent's interest in it, either for the benefits at stake or for the importance of not being overruled by the principal.

The formalization developed by Aghion and Tirole gives insight into the trade-offs between giving autonomy to the local community in their management decisions over the use of resources and maintaining the authority of the central administration over these management decisions. This model helps to identify the major determinants of effective delegation. It is then used in the following to analyse the procedure of definition of the GELOSE contract and to identify the key parameters of delegation. 


\section{The GELOSE policy}

In Madagascar, two major features of the institutional setting for biodiversity management underpinned the emergence of the GELOSE policy. The National Environmental Actions Plan (NEAP), run by the National Office of the Environment (ONE), was initiated in 1992. In its first phase, it focused on biodiversity conservation in 46 protected areas (PA). ${ }^{5}$ Twenty-one Integrated Conservation and Development Projects (ICDPs) were established around PAs for conservation purposes. They provide support for resource uses in adjacent areas as a means of compensation. In the second phase of the NEAP (1997-2002), more attention was paid to developing the economic value of biodiversity.

The decentralization policy launched in April 1996 focused on the creation and granting of powers to institutions defined at regional and local levels, and on the definition of development policies at those levels. Regional and municipal governments (or district authorities) were created by aggregating several fokolona that were the basic administrative and territorial entities. This contributed to a decentralization of central government control over natural resources and biodiversity that was intended to solve the problems of overlapping responsibilities and management competencies. This decentralization involved modifications of property rights, not yet fully achieved.

\subsection{Implementation of the GELOSE policy}

The GELOSE policy was instituted by the act 96-025. It provides for the contractual transfer of management responsibility for forests and other renewable resources from the central government to rural communities, organized into associations called 'communauté locale de base' (CLB, i.e. grassroots community), on a country-wide scale. The act encompasses all the resources of the state domain, i.e. forests, wild fauna, and flora, together with water and rangeland. It institutes the CLB as an entity with legal status and legal personality. It also provides for recognition of customary rights. Delegation is formalized by a contract for a renewable three-year period. The GELOSE policy is implemented through institutional arrangements. This nation-wide contracting process goes beyond the well-known figure of the basic contract for protecting biodiversity between public institutions and individuals (Simpson and Sedjo, 1992), by involving local communities and potentially all resources.

The contracts delimit exclusive collective rights to be transferred to the CLB members in a defined area and obligations to be followed for access to and use of the ecosystem resources. Contracts are set up

${ }^{5}$ These consist of 18 national parks where non-commercial rights of use are granted over dead wood for fuelwood and over, collection of fruits and barks for social and religious practices (burial, customary rites); 23 special reserves, characterized by a total ban on use or access, except for scientific purposes, and five fully protected natural reserves with a ban on all rights of use. PAs are under the authority of a conservation agency, the Agence Nationale de Gestion des Aires Protégées (ANGAP), set up under the first NEAP. They are managed directly by the ANGAP or delegated to conservation bodies such as Conservation International or WWF. 
after a process of negotiation between three parties, central government representatives (i.e. the Forest Administration), the municipal government, and the CLB. Accommodation of interests is reached with the support of a mediator. Contracts are designed for each ecosystem type and for each community which has developed a particular set of uses for the ecosystem resources. They include a formal agreement among the community members for social enforcement of the contract terms (the 'dina'). The GELOSE procedure can be seen as a way to improve the linkage between the legal institutional framework based on state ownership of natural resources and the customary laws governing the use of natural resources within local communities (Bertrand and Weber, 1995). One of the main issues regarding the GELOSE policy is to determine how the transfer of property rights through the law - its enforcement and administration is liable to affect the behaviour of users of natural resources (Barzel, 1989; Babin et al., 1999).

Prior to the NEAP and GELOSE implementation, the central Forestry Administration managed the natural resources according to a timberoriented and well-established legal system of resource harvesting regulation and of taxation. Nevertheless, this system did not achieve effective control over actual multiple uses of forest resources. A state ownership regime over the 'state domain' covering most land and natural resources encompassed the PAs and gazetted forest (for biodiversity and forest conservation), the productive forests (for timber and fuelwood production) and agricultural land (for crop production). Over the entire 'state domain', the central government authorizes customary users' rights, excluding the right to sell natural resources. These rights are limited and not recognized on a legal basis, but they have a social legitimacy (Razafindrabe, 1997). Rights for commercial exploitation and management rights are attributed by the Forestry Administration over agricultural lands and forests, or productive forests. Productive forests are divided into concessions granted to timber companies. Administrative licences are required for hunting and fishing. Felling and clearing on agricultural land are subject to the authorization of the central government representative in the village, the Local Commission for Security (LCS), and to felling permits attributed by the Forest Administration. Private land ownership rights, guaranteed by an official land title, are effective over 6-10 per cent of the national land. But since decentralization has been implemented, ownership rights obtained by clearing can be registered by the municipal government and exchanged even without an official land title.

With the implementation of the GELOSE policy, a redefinition of the 'state domain' has become necessary. The state remains the sole legal owner of natural resources over the entire national territory (except when private land ownership rights have been defined) and the guarantor of their integrity. But some autonomy is given to local communities in their decisions about resource uses on a defined community area. In the contracting process, local communities can be granted exclusive use and management rights over the 'state domain' in order to foster security of land tenure and resource management. GELOSE is seen as a way of sharing 
property rights over biodiversity to reduce the government cost of control (Babin et al., 1999; Aubert, 2002).

\subsection{The contracting process}

Four steps ${ }^{6}$ must be completed before the contract is signed. The transfer of rights then becomes effective for three years.

\section{The request}

The process is initiated through a request ${ }^{7}$ expressed by the local community for the right to manage some specific natural resources. This request is transmitted by an operator who may be either the ONE or an NGO. The process is based on a case-by-case approach, which is contingent to the local context and to specific issues. In many cases, the main issue is to limit the assignment of permits by the Forestry Administration to people outside the community or to avoid entry into a PA. When the request is accepted, negotiation is initiated with the state representative (i.e. the Forestry Administration) about the mode of transfer.

Identification of stakeholders' interests and claims

To implement the law and draw up contracts, information is required on the biological state of the resource, its boundaries, the nature of current uses and the various claims for allocation of rights over the ecosystem. This information is reviewed in this second stage. The delimitation of the area and of the resources covered by the contract is a crucial issue negotiated not only with the Forestry Administration but also with the neighbouring communities. $^{8}$

Information is acquired with the support of a mediator who facilitates dialogue between the administration and local stakeholders. One of the major features of the GELOSE policy is the way it interlinks the legal system managed by the Forestry Administration and the customary system that governs the uses of resources within the communities. Hence, the mediator must be familiar with the practices of both systems. The mediator has been seen as an external and neutral agent whose role ends with the signature of the contract. Ideally mediators are state agents who receive specific training before becoming mediators (Andriatahiana et al., 1996). ${ }^{9}$ They must originate from the region where they work. The mediator plays an important part in the process of fostering compatibility between the two parties' objectives, with regard to what may be allowed within the forest law and the nature of the community's claims. Part of the mediation process consists in identifying medium-term objectives with respect to the

${ }^{6}$ The procedure, and the different steps it encompasses, has been specified by the National Office for the Environment in charge of the GELOSE policy.

7 This request is called the 'claim' ('déclaration d'intention').

${ }^{8} \mathrm{~A}$ map of the area is established detailing the allocation of the delimited community area to agricultural uses, harvesting of forestry products, etc.

${ }^{9}$ Since 1998, the Malagasy government has hired people and trained them to operate as mediators. 
management of natural resources through dialogue between community members and between the community and the administration (Weber, 1995, 2000). Commitment to these objectives is seen as a means for resolving conflicts, and rules are designed on the basis of these objectives. The information on the current and potential uses of the resources becomes common knowledge for all the contracting parties.

The contract and its terms and conditions

The third step consists in drawing up the contract. During the mediation process, the CLB takes part in the decisions about permitted land uses over a specific area. These are included in the collective management plan for natural resources, called the 'Plan d'aménagement et de gestion simplifiée', which is at the core of the contract and is described in a map. It gives the framework within which the CLB will decide who can make use of the resources.

The technical conditions for exercising community management rights as well as the conditions of non-compliance that entail suspension of the contract by the government representatives are laid down in the terms and conditions appended to the contract. These conditions refer to the prohibited areas or species, the limits of resource use by households such as quotas, technical restrictions of exploitation, the felling specification, the nature of the permits that may be granted directly by the community, and the financial resources the community is allowed to derive from delivering non-commercial but also, in some cases, commercial usage rights (taxes and fees).

Control and sanctions

The fourth stage aims to describe the control and sanction mechanisms that will ensure that the community complies with the designated rules. Sanctions, mainly fines, are imposed through the 'dina', which is a customary community convention used in the Malagasy society to settle social conflicts. Thus, the CLB is responsible for ensuring that community and non-community members comply with the rules specified in the contract. Supervision is performed by an executive management structure set up within the CLB. The 'dina' is approved by the municipal government and proclaims the legitimacy of the CLB. The reliance on the 'dina' for contract enforcement helps to bridge the gap between the legal system and the customary institutions (Aubert, 2002).

\subsection{Initial achievements}

The first contracting process was initiated in 1997 in a forest zone near the ICDP's Marojejy National Park. In 2001, 32 contracts were signed and 53 were about to be signed (ONE, 2001). These contracts were analysed using a three-fold methodology. An extensive survey of existing studies (by field experts) and of actual contracts was undertaken. A focus group, including representatives of ONE and researchers, was set up to establish a typology of these contracts and a framework for their analysis (Aubert et al., 2001). Field work was done in two regions to study actual contract enforcement, on the basis of this framework (surveys in five villages near the Andapa ICDP, 
where contracts have been signed over the last three years). Observation of the start of the negotiation process for one contract in a third region (on raphia on the East Coast) completed our analysis. The contracts were reviewed by ONE to obtain a broad overview of the achievements and difficulties of the GELOSE Policy (ONE, 2001; Maldidier, 2001).

As shown in appendix 2, transferred resources are mostly forest resources located on the periphery of protected areas. This is an illustration of the early rationale of GELOSE, i.e. to prevent settlements in PAs and gazetted forests. This can also be linked to the role of the operator, the contracts being implemented where a pre-existing structure plays a role in resource management or conservation. The case studied showed that these operators, especially international nature conservation agencies or NGOs, are not only the transmitters but also the instigators of the community request. The operators, involved in natural resources management long before the GELOSE process began, and thus known by the local communities, usually take part in the process by appointing their own informal mediators. They may even prevent the formal mediators from contributing efficiently to the negotiation process. These operators have their own objectives and may influence the autonomy of the other contracting parties in the definition of management rules (Péchard, 2002). This issue is due partly to a questioning of the legal mediator's legitimacy that occurs in most cases, even though objective criteria for selection and capacity building of agents chosen to assume the role of mediator have been developed. These cannot always be fulfilled due to a lack of financial resources. Consequently, the mediator's role has often been restricted to operational tasks, such as drafting the terms and conditions of the contract (Maldidier, 2001).

Moreover, the transferred resources are often over-exploited and the ecosystem degraded. There is broad awareness about management improvement requirements, but freedom of action for improvement is limited. Hence, one of the most important requirements stressed by Ostrom (1999) for achieving successful community-based forest management is not met.

The transferred rights are usually non-commercial use rights as far as timber and forest resources are concerned and commercial withdrawal rights mainly for fuelwood, raphia and other non-forest timber products. Studies have shown that, in some cases, the allocation of non-commercial withdrawal rights serves the interests of local communities by allowing them to prevent private loggers or traders from exploiting their resources (Maldidier, 2001). CLB are granted rights to exclude outsiders: migrants, private loggers.... Real management rights, defined by Schlager and Ostrom (1992) as 'the right to regulate internal use patterns and transform the resource by making improvements', are not transferred in most of the cases studied. CLBs are not allowed to convert forested areas to other uses such as farming. Authorization for clearing remains under the Forestry Administration's authority. In some instances, the clearing ban has been reinforced with the GELOSE contract, as is the case in the Andapa area (Péchard, 2002).

Compliance of the CLB members with the terms of the contract is encouraged by the following main incentives. CLB members may be 
compensated for accepting the clearing ban. They may be given the right to choose previously forbidden patterns of resource uses, such as livestock grazing in forested areas. They can also stipulate, through the contract, the conditions under which endangered resources are exploited by outsiders (e.g. the raphia exploitation by traders is regulated by rules stated in the contract). They may receive guarantees regarding the conservation of current land uses. Agricultural land use may be legalized in some forested areas in exchange for a community effort to limit exploitation and rehabilitate other forested areas. In the Andapa area, part of the national park has been set aside, downgraded to ensure that a significant area can be transferred to the communities. ${ }^{10}$ Grants and training for forest maintenance or agroforestry practices may be provided, though this is not widespread.

Because implementation of GELOSE was claimed to be too slow and complex, a new forestry policy was defined in 1997 to foster the contractual management of all types of forests, except for protected areas. This policy is instituted by the act 2001-122 and simplifies the conditions under which the rights transfer and the contract may be implemented and enforced. But less emphasis is placed on enforcing secured land tenure.

\section{Some insights for analysing the GELOSE policy}

The Aghion and Tirole framework of analysis is applied to the general GELOSE policy procedure. The hierarchical relationship between the central government, which owns the natural resources over all Madagascar, and the local communities, which claim to have rights over the use of these resources in specific areas, can be compared with the relationship between a principal who hires an agent to implement a project and this agent, as described in the Aghion and Tirole (1997) model. Through the GELOSE contract, the delegation deals with decision right over natural resources previously held by the central government.

\subsection{The stakeholders and the contracting parties}

As previously noted with regard to the legal system, two actors play a prominent role in natural resources management. The first is the Water and Forestry Administration, ${ }^{11}$ which defines and implements the timberoriented forest policy. The other is the municipal government. As part of the decentralization process initiated in Madagascar in the mid 1990s, it was set up and given control over territorial development policies. Hence, these two institutions are both parties to the contracts that transfer rights to local communities. However, the municipal government does not constitute an effective key player in the process. It generally has no more than a consultative role in the process of contract definition. It is given a right to supervise contract implementation to ensure that resource management is effective and not prejudicial to the local and regional development

${ }^{10}$ Ramboavelo J., WWF Ecological Unit of Andapa IDCP, Personal Communication.

11 This administration has staff throughout Madagascar who act as state representatives for natural resources management. These local representatives are those who sign the GELOSE contracts. 
plans. But our field work showed that the participation of the municipal government in the contract does not substantially modify the scheme of the management rules to be defined and, hence, the possible benefits resulting from them. Therefore, in what follows, and for the purpose of drawing a parallel between the Aghion and Tirole model and the GELOSE contract definition, we will refer to the contract as if it were signed only by the central government, represented by the Water and Forestry Administration on the one hand, and by the CLB on the other. The decision, equivalent to that of choosing between various projects that will yield different benefits, is basically that of choosing the management plan. The chosen rules will determine the costs and benefits to the two parties.

\subsection{The benefits of delegation}

Benefits of contract implementation for the two parties may vary widely from one to another, as all the contracts do not encompass the same natural resources and the same uses and rights. The extent of the resources and of the uses covered, and then the degree of autonomy given to the local community for defining natural resources management under the contract, depend both on the request of the local community, which is based on its own specific needs and preoccupations, and on the interests at stake from the viewpoint of the central government. Implementation of the GELOSE contract may modify existing customary rules and/or create new ones, specifically designed to ensure sustainable management of the resources considered in the contract, or it may simply provide for legal enforcement of existing customary laws. The CLB becomes responsible for ensuring effective implementation of the contract rules and compliance of its members and other users with the designated rules. Depending on the specific terms of the contract, the local community may be given the effective right to decide who can benefit from the natural resources considered in the contract and how each agent can benefit from them. Or, when commercial rights are assigned by the Forestry Administration, it may simply be given the right to enforce compliance by community members and outsiders with the natural resource management rules specified in the contract.

Despite the diversity of contract implementation, some of the benefits arising from these contracts can be identified. For the local community, a major benefit appears to be that of securing community land uses and access rights to the community area and resources, and that of excluding outsiders, mainly members of other communities, from using the natural resources covered by the contract. By delimiting plots on the map standing for the collective management plan for natural resources and representing areas over which rights transfer is requested, GELOSE translates customary management rights into a legal form. This is not directly associated with assignment of full property rights to the community members, ${ }^{12}$ but it is expected by the community members to facilitate the future recognition of private property rights by the state. This may be highly beneficial for certain members, since this process of state recognition of private property

12 This mechanism is called 'sécurisation foncière relative' (relative security of land rights). 
rights is known to take a long time and to entail high costs. Hence, private interests in land entitlement contribute, in many cases, to the willingness of local community members to become involved in a GELOSE contract. The desire to control land access by local communities, collectively or privately, and to exclude people from outside the community are powerful driving forces for requesting a contract. The community may also receive a share of the financial resources by charging certain users' rights, collecting fines, and levying certain users' fees or taxes such as 'ristournes' and 'redevances'. The assignment of permits may, in some cases, come under the authority of the CLB.

The Forestry Administration's main interest in this process is to reduce the costs of supervision and to limit the conflicts between local users, and between local users and outsiders. These conflicts often end in bush or forest fires or in settlements inside the protected areas, or in illicit forest clearing. It can also benefit from the improved availability of information and reinforced controls over natural resources exploitation achieved by the new regulation system managed by the CLB. It can thereby levy more taxes ('redevances') for the allocation of commercial withdrawal rights or 'permits' over certain resources, even though the tax rates are lowered through the contracting process. Hence, both the central administration and the local community stand to gain by ensuring that established rules over natural resources are respected.

The municipal government may have the same conflicting interest in taking part in GELOSE. The tax income from the commercialization of rough products, called the 'ristournes', have to be shared with the local community. Nevertheless, it obtains better information about natural resources exploitation, and thereby levies more 'ristournes'. Another source of conflicting interests may be the trade-offs between the municipal government's interest in territorial economic and social development on the one hand and biodiversity conservation on the other.

The major benefit of the contract for society as a whole arises from the more sustainable management of natural resources, given that it is in the interest of local stakeholders (CLB, municipal government) to ensure the long-term conservation of resources in the area over which they have secured rights of control and exclusion.

\subsection{The information issue}

At the beginning of the process, both the local community and the central administration are uncertain about the benefits that will result from different sets of rules enforced for the management of natural resources. The definition of the terms of each contract involves a process of identification and of understanding of what is at stake that will determine the decision about how to govern the management of natural resources (Antona and Babin, 2001). Both parties are involved in acquiring information and defining how much information to obtain about the benefits of the different potential management plans. Such information mostly relates to the boundaries of the area over which the contract will be enforced, given that it may be contested by other communities, and to the impact of the different rules for the management of the natural resources of that area. Through 
the GELOSE policy, the local communities have incentives to acquire information about how to better manage and control the exploitation of the resources as stated by the Aghion and Tirole model. Hence, contractual delegation may result in better knowledge about how to manage the natural resources in a sustainable manner, and better control of the way the resource is used, given the greater involvement of the local community in decision making.

The model supports the idea that local communities should be given the right to manage natural resources over which they are better informed. This reinforces the basic argument behind the community collaborative approach and the involvement of local populations in natural resources management: the grassroots communities possess a capacity to manage information and to exercise control that cannot be equalled by the central government (Kant, 1997). But this argument is challenged by the field of research on local governance. According to these analyses, local governments may have better capacity than grassroots communities to make use of the information and are assumed to effectively claim and exert power (Ribot, 1999; Agrawal and Ostrom, 2001).

\subsection{The congruence issue}

The other aspect pointed out by the Aghion and Tirole model is the need for congruence between the central government's and the local community's interests. When formulating its request, the local community can ensure that it is not requesting transfers of rights over natural resources for which the central government's interests diverge too strongly from those of the local community, by excluding resources over which conflicts are too strong, for example. Furthermore, the dialogue established through mediation during contract negotiation may modify the expectations of the contracting parties, and hence, increase the congruence in their objectives, thus favouring delegation. The mediation process can be thought of as a means to achieve lesser dissonance and, therefore, better congruence between the central government and the local community.

The government is rarely willing to delegate responsibility for resources that generate substantial benefits, and which are regarded as strategic. This is clearly the case for shrimps, which cannot be included in the management plans proposed by the community and which remain under state control. Furthermore, when tourism benefits are expected in some areas, these are less likely to be concerned by GELOSE contracts. On the other hand, as mentioned earlier, GELOSE contracts are more likely to be established in areas where resources are severely degraded, and where government interests are limited.

Moreover, congruence of interests emerges around the transfer of exclusion rights, which can be seen as a benefit both by the central government and by the CLB, as commonly observed in the studied contracts.

\section{Discussion}

The first part of the discussion focuses on the involvement of certain stakeholders, and on organizational aspects, which are not highlighted 
in the model. These are the collective nature of the parties and the role of NGOs. Our second concern relates to the freedom of action associated with the actual transferred rights. Along with the freedom of action, the nature of the contract is at stake. A major issue is to determine whether implementation of the GELOSE policy gives rise to a real transfer of rights or if it is simply a policy by which local communities are made to manage resources in an externally defined way stated in the contract (Aubert et al., 2001).

\subsection{The collective nature of the parties}

In the model, each agent is considered as a single decision-making entity. But both the local community and the Water and Forestry Administration are, in fact, collective levels of decision. Divergence of opinion may be expressed among their members.

The institutional component of the GELOSE policy linked to the creation and functioning of the CLB, which is intended to represent collective local interests and implement the GELOSE contract, should not be underestimated. Through the GELOSE contract, the previous individual control exerted by the forest officer is now replaced or reinforced by local collective control, and is thus, generally enhanced. As already mentioned, enforcement of the contract by the local community relies on the customary system of social rules through the definition of a 'dina'. In the 'dina', rules are clearly stated and sanctions are imposed for each type of offence that might be encountered. Reliance on the 'dina' to enforce the contract has several advantages. Like all customary rights, the 'dina' may evolve in response to changing resource dynamics, for example. Through this enforcement mechanism, adaptive management becomes possible. Nevertheless, problems of internal consistency may appear. The effectiveness of the rules will depend on the distribution of power among the community members. Rules are effective when they constrain a minority of members, or the least influential ones (lumberjacks), or when they are supported by a majority (Péchard, 2002).

Within the Water and Forestry Administration, the agents working directly for the central government do not always have the same interests as those living near the community and directly in charge of supervising the use of natural resources. Before the GELOSE implementation, the latter were responsible for delivering permits, for controlling the exploitation of natural resources, and for sanctioning and collecting fines. Due to the lack of control within the administration, they were not obliged to systematically report transactions to their supervisor. They may thus be unwilling to implement a GELOSE policy which takes away a part of their income. On the other hand, for the central government, the GELOSE policy may be a way of gaining information and transparency about natural resources management, since reports are written and made public by the CLB and verified both by the administration and by the municipal government.

\subsection{The legitimacy of NGO involvement}

One of the objectives legitimizing the GELOSE policy was its contribution to a more sustainable management of biodiversity, whose benefits 
extend beyond the scope of local communities and central government. Biodiversity conservation has some of the features of a global public good, which is of concern for environmental NGOs, and explains their involvement in GELOSE policy implementation.

NGOs may actually have major interests at stake for several reasons. Firstly, more funds are now devoted to community-based natural resources management in response to the recent orientations of international institutions. Secondly, the GELOSE approach solves prior conflicts between NGO agents, previously responsible for exercising control, and local people. NGO agents may even gain political influence from the implementation of a management transfer. Thirdly, they might gain some power over natural resources regulation, since local partners are more likely to be influenced.

The involvement of the NGOs in the contracting process, which may result in close links between the mediator and the NGO operator of the GELOSE policy, may have adverse effects. Firstly, it may be a source of bias in the negotiation process, since the mediator cannot always be considered as neutral. Secondly, the NGO, which gets involved in the process, often appears as the provider of the new rights. Thus, the process eases relations between the NGO and local people, but does not modify relations between local people and government officials as it is supposed to do. Finally, the relation that develops between the NGO and the CLB during the implementation process may affect the reliability of the contract. Unlike the formal mediator, NGOs do not leave the process after signature of the contract, but support its implementation. NGOs involved in biodiversity conservation are often external donor agencies and are associated with major financial and political interests. For the central government, enforcing the contract might then be more closely related to the desire to maintain relations with the conservation agency than to provide management rights incentives (Péchard, 2002). Consequently, the NGOs often become a central player in the governance mode they implement but in which they do not constitute a contracting party. As their intervention is limited in time, the viability of the arrangement should never be dependent upon their presence.

\subsection{The nature of the contract and enforcement issues}

Transferred rights are mainly exclusion rights, seldom management rights. ${ }^{13}$ This limits the freedom of action actually obtained by the CLB. Exclusion rights are transferred because the interests of the central government and those of local communities converge on this point (see section 4). The CLB has thus gained formal authority to decide who is allowed to use the natural resources. When management rights are formally transferred, they are actually shared with the State. The management transfer is contingent to the acceptance of local rules by the State. This is justified by the need to safeguard the public interest and to signify that the government remains the legal owner of the resources. However, it limits the CLB's capacity to influence rule making. What is at stake is the CLB's

13 The GELOSE policy is nevertheless often qualified as a process of management rights transfer. 
autonomy to devise rules for the use of natural resources in its area; likewise, the capacity of the rural community to exert its rights and effectively enforce them (Agrawal and Ostrom, 2001).

Do the rules stipulated in the GELOSE contracts result from an explicit negotiation between the central government and the CLB or do they consist in a package of rules, defined and proposed beforehand for acceptance by local people? Addressing this question may help to evaluate the incentives arising from the policy. Emphasis is placed on the symmetry of the relation between the parties during the negotiation, and especially on the gains and losses resulting from the contract. According to Maldidier C. (2001), 'despite the asymmetry in their relation (administration and local communities), forms of compromise reflect an implicit negotiation, whose general terms would be: Water and Forests Administration delegate a share of their responsibilities in forest control, in exchange for a limitation of community user rights and their commitment to self-regulation of forest clearing practices'.

In line with Aghion and Tirole's model, the rules designed in the GELOSE contracts can be classified as follows (i) Rules for which the stakes are high for the central government. Regulation of forest clearing practices and resources inside protected areas remain under the responsibility of the government services. (ii) Rules for which the stakes are high for local people but not so high for the central government, and which can now be tailored to local conditions. This is the case of boundary rules. These rules either confirm de facto rules or raise conflicts to be solved locally. (iii) Some rules are restrictive but are associated with new responsibility over others. In some contracts, wood harvesting is now restricted to domestic use only. But at the same time, these contracts recognize the new possibility for CLB members to obtain wood permits directly from the CLB committee without referring to the forest officer anymore.

GELOSE contracts give local people the right to tailor certain rules and acquired legal rights and responsibilities over resources located in what is now accepted to be their territory. Open discussion within the village committee for modifying the level of wood permits, inconceivable a few years ago, is now frequent. Nevertheless, further progress is needed to give local people a real choice between all possible rules in respect of the public interest. Negotiation is generally implicit, meaning that rules are mainly defined outside the mediation arena. The relation between the parties during the process appears to be one of 'proposal-acceptance' (proposal of a package of rules by the central government and acceptance by the CLB), rather than an explicit negotiation where consensus emerges within the negotiation arena. Given the interests at stake for the CLB, it may be considered too hazardous to negotiate and to risk a total refusal of rights transfer. Consequently, the proposed rules are always accepted. However, this acceptance does not necessarily mean a strong commitment to all the rules and an effective enforcement of the contract. For instance, in the Andapa region, rules that restrict wood harvesting to domestic use only, are poorly enforced. These rules prohibit the sale of wood to people who are not members of the CLB, but people cannot afford to give up their revenue 
from selling harvested wood, and no incentive system other than a simple ban has been proposed to regulate wood sales to outsiders.

A major stake is the requirement in terms of human capacity for defining and effectively implementing management plans on behalf of the local community, and for supervising them. Some rights are legally transferred to the CLB, but as yet they still lack recognition from outsiders, from local forest officers, and from NGOs.

\subsection{The reliability and robustness issues}

If the government were to learn that some resources have a higher value outside the contract than within, it might not be willing to respect its commitment to give control over resources management to the local community. The government's freedom to reverse the process and to take back the rights previously granted to the local community through the GELOSE process must then be considered. As the government always remains the owner of the resources, it can unilaterally decide to terminate the contract if forestry legislation changes. In that case, the CLBs might be compensated for their loss even if it is not clearly defined. The contract, in its first stage of implementation, covers a short three-year period, and apparently there is no irreversibility in the transfer. Furthermore, while the CLB has a specific mechanism for enforcing the contract - the 'dina' - the forestry administration does not. This should mean that the CLB is subject to a much higher level of requirement in the implementation of the contract. Nevertheless, the very short time since the first contracts were implemented and the limited number of contracts already signed make it very difficult to provide a clear answer to this issue. Little information is available to assess the reliability of the contracts and the actual trends.

Furthermore, as already mentioned, there is substantial variability among the contracts, both in terms of the resources that are involved and of the uses of these resources. Hence, what is at stake in each contract cannot always be compared. Some contracts address only personal uses of natural resources, and do not entail major conflicts of interest. Other contracts are defined over large territories and include large-scale commercial uses. Hence, the first kind of contract is less likely to be challenged than the second.

It is worth noting that the GELOSE procedure has not been defined once and for all, except for the elements clearly stipulated in the law. It is liable to evolve over time, depending on its success. ${ }^{14}$

\section{Conclusion}

Faced with natural resources and biodiversity depletion, and with the failure of central policies, Madagascar chose to modify its property rights regime covering biological resources. Economic analysis of the mechanisms set up within the GELOSE policy sheds light on some of the issues. As shown by our application of the Aghion and Tirole model, the GELOSE

14 The success of the procedure is basically measured in terms of the quantity of contracts signed throughout Madagascar, though a more appropriate evaluation procedure, taking account of qualitative factors not directly apparent with this single criterion, is now being considered. 
policy is designed to delegate rights over natural resources to the local communities. It intends to give new autonomy to these communities in their uses of natural resources, to give them incentives to collect information about the state of the resources - users and current uses - and to transmit this information to the administration through the contracting process. This delegation is clearly in line with the desire of international financial institutions for the central government to limit its role and to concentrate on its basic functions.

Congruence between the interests of the parties appears to be a major concern for the actual development of the GELOSE contracts. This can be linked to the ambition of the GELOSE policy to interlink the legal system of management, which has formal authority but does not have sufficient control capacity to fully supervise resources management or to resolve conflicts, and the customary system that works within the rural communities. Though having no legal status, the latter is always considered to have true legitimacy (Razafindrabe and Thompson, 1994). Each system has its own objectives. The congruence of objectives has been shown to be a key factor for delegation. An interesting feature of the GELOSE policy is the presence of a mediator during the negotiation process who facilitates communication and contributes to ensuring that the objectives of the parties become congruent. Nevertheless, this official mediation is difficult to actually implement and has led in some cases to informal mediation (Péchard, 2002).

Another element is the need for the rural community to organize itself into a legal association - the CLB - to claim rights over resource management and to become involved in a GELOSE contract. The constitution of such associations is favoured by the decentralization process that brings decision-making processes and local economic interests closer together. But it may also limit the participation of some members of the rural communities such as migrants. The success of the devolution process depends on the capacity of the local communities to exert real authority in devising effective management rules, and then to supervise natural resources management. The political decentralization process may have been a pre-condition for implementation of the GELOSE policy. It reinforces the local structures and enhances the capacity building at the local level and the control over natural resource management by the local communities. Thus, it may favour the existence of spontaneous requests for GELOSE contracting, even though these were observed only in few cases. Conversely, the GELOSE policy gives legitimacy to the control by municipal governments over natural resources pertaining to municipal areas.

Though the GELOSE contract may seem attractive in terms of the rights it gives to local communities, the GELOSE policy has not achieved its goal in terms of numbers of contracts signed in its first four years of implementation (Aubert, 2002). As already stated, transferred rights are mainly exclusion rights. The common point of most contracts is that the CLB receives the right to exclude non-members from access to the transferred resource over delimited areas. When the CLB authorizes access to transferred resources, they may levy user fees. More manageable policies for transferring resources management to local communities have been implemented since the GELOSE policy. But they do not involve the securing 
of land and can be compared with usual community-based management plans enforced by the Forestry Administration and NGOs.

\section{References}

Aghion, P. and J. Tirole (1997), 'Formal and real authority in organizations', Journal of Political Economy 105: 1-29.

Agrawal, A. and E. Ostrom (2001), 'Collective action, property rights and decentralization in resource use in India and Nepal', Politics and Society 29: 485-514.

Agrawal, A. and J. Ribot (1999), 'Accountability in decentralization: a framework with South Asian and West African cases', Journal of Developing Areas (33): 473-502.

Antona, M. and D. Babin (2001), 'Multiple interest accommodation in African forests management projects: between pragmatism and theoretical coherence', International Journal of Agricultural Resources, Governance and Ecology 1: 286-305.

Aubert, S. (2002), 'La Gelose à Madagascar', in M.C. Cormier-Salem et al., Patrimonialiser la nature tropicale. Dynamiques locales et enjeux internationaux, Paris, IRD Editions - Collection colloques et séminaires.

Aubert, S., E. Motte-Bienabe, and, G. Pechard (2001), ‘Regards Croisés de praticiens, d'économistes et de juristes pour une classification des contrats GELOSE à Madagascar', CIRAD/LAMETA, $34 \mathrm{p}$.

Andriatahiana, V., B. Rakotomandimby, J. de Montgolfier, and M. Razafindrabe, (1996), 'Les médiateurs environnementaux de Madagascar. Cadre institutionnel. Système de formation et conditions réglementaires d'exercice professionnel', Office National de l'Environnement/CIRAD-Madagascar.

Babin, D., A. Bertrand, J. Weber, and M. Antona (1999), 'Patrimonial mediation and management subsidiarity: managing pluralism for sustainable forestry and rural development', Pluralism and Sustainable Forestry and Rural Development, (FAOIUFRO-CIRAD), Rome, Italy, pp. 277-305.

Barzel, Y. (1989), Economic Analysis of Property Rights New York: Cambridge University Press.

Beaumont, P.M. and R.T. Walker (1996), 'Land degradation and property rights', Ecological Economics 18: 55-66.

Bertrand, A. (1995), 'Forums locaux, aménagements du territoire et planification nationale: Les enjeux et les defis des politiques foncieres et forestières', in E. Le Roy et al. (ed.), La Sécurisation fonciere en Afrique, Paris: Karthala, pp. 365-370.

Bertrand, A. and M. Razafindrabe (1997), 'La problématique foncière à Madagascar en 1997', CIRAD- CERG2R.

Bertrand, A. and J. Weber (1995), 'From state to local commons in Madagascar: a national policy for local management of renewable resources', in The Voices of the Commons, IASCP, 14 pp. Bodo, Norway.

Cardenas, J.C. (2000), 'Thinking globally and getting others to act locally: polycentricity and the conservation of biodiversity', Workshop in Political Theory and Policy Analysis, Indiana University.

Crémer, J., A. Estache, and P. Seabright (1996), 'Decentralizing public services: what can we learn from the theory of firm?', Revue d'Economie Politique 106: 37-60.

Cumming, D.H.M. (1999), 'Living off "biodiversity": whose land, whose resources and where?', Environment and Development Economics 4: 220-23.

Dickens, V. (2000), 'Integrating biodiversity into environmental management systems', International Affairs 76: 373-374.

Ganzhorn, J.U., P.P. Lowry, G.E. Schatz, and S. Sommer (2001), 'The biodiversity in Madagascar: one of the world's hottest hotspots on its way out', Fauna and Flora International Oryx 35: 346-348.

Gerard-Varet, L.-A. (1994), 'Théorie des incitations et analyse des procédures de la décentralisation', in J. Affichard (ed.), Décentralisation des organisations et problèmes de coordination: les principaux cadres d'analyse, Paris: L'Harmattan, pp. 19-38. 
Grossman, S.J. and O.D. Hart (1986), 'The costs and benefits of ownership: a theory of vertical and lateral integration', Journal of Political Economy 94: 691-719.

Hanna, S. and M. Munasinghe (1995), Property Rights in a Social and Ecological Context: Case Studies and Design Applications, Stockholm/Washington: Beijer International Institute/World Bank.

Hufty, M. and F. Muttenzer (2002), 'Devoted friends: the implementation of the convention on biological diversity in Madagascar', in P. Le Prestre (ed.), Governing Global Biodiversity, the Evolution and Implementation of the Convention on Biological Diversity, Brookfield: Ashgate Publishing, 450 pp.

Kant, S. (1997), 'Integration of biodiversity conservation in tropical forest and economic development of local communities', Journal of Sustainable Forestry 4: 33-61.

Larson, A.M. (2002), 'Natural resources and decentralization in Nicaragua: are governments up to the job?', World Development 30: 17-31.

Maldidier, C. (2001), '1996-2000: La gelose a 4 ans. La décentralisation de la gestion des ressources renouvelables à Madagascar', ONE, Cellule Gelose, Madagascar.

Oates, W. (1972), The Political Economy of Fiscal Federalism, Lexington, MA: Lexington Books.

ONE, Cellule Gelose (2001), 'Bilan des contrats', ONE, GELOSE, Antananarivo Madagascar.

Ostrom, E., L. Shroeder, and S. Wynne (1993), Institutional Incentives and Sustainable Development: Infrastructure Policies in perspective, Boulder, CO: Westview.

Ostrom, E. (1999), 'Self governance and forest resources', CIFOR Occasional Paper n`20, CIFOR, Bogor, 19 pp.

Péchard, G. (2002), Transfert de gestion des ressources naturelles aux communautés locales dans un contexte d'aires protégées. Le cas de la région d'Andape à Madagascar, in Séminaire commun ENGREF LAMETA. La conception et la mise en cuvre des politiques de protection de la nature : problématiques et controverses scientifiques, INRA, Montpellier, 12-13 septembre.

Razafindrabe, M. and J. Thompson, (1994), 'Local governance in Madagascar', KEPEM/USAID. Antananarivo.

Razafindrabe, M. (1997), 'L'aménagement et la gestion des terroirs, La structuration du monde rural vers une option d'aménagement et gestion des espaces ruraux', Université verte, L'aménagement et la gestion des terroirs, CIO-SARL.

Ribot, J. (1999), 'Decentralization, participation and accountability in Sahelian Forestry', Africa 69: 23-65.

Schlager, E. and E. Ostrom (1992), 'Property-rights regimes and natural resources: a conceptual analysis', Land Economics 68: 249-262.

Schmid, A.A. (1995), 'The environment and property rights issues', in D. W. Bromley, The Handbook of Environmental Economics, Oxford and Cambridge, MA: Blackwell, pp. 45-60.

Sedjo, R.A. (1995), 'Property rights externalities, and biodiversity', in T. M. Swanson, The Economics and Ecology of Biodiversity Decline The Forces Driving Global Change, Cambridge: Cambridge University Press, pp. 79-88.

Simon, H.A. (1947), Administration et processus de décision, Paris: Economica.

Simpson, D.R. and R.A. Sedjo (1992), 'Contracts for transferring rights to indigenous genetic resources', Resources, 1-6.

Smith, B. (1985), Decentralization: The Territorial Dimension of the State, London: George Allen.

Weber, J. (1995), 'L'occupation humaine des aires protégées à Madagascar: diagnostic et éléments pour une gestion viable', Nature, Sciences, Sociétés 3: 157-164.

Weber, J. (2000), 'Pour une gestion sociale des ressources naturelles', in D. Compagnon and F. Constantin, Administrer l'environnement en Afrique, KarthalaIfra, pp. 79-106. 


\section{Appendix 1: The Aghion and Tirole model}

In this model, the utilities of the principal and the agent in the cases of delegation and integration are described. The optimal effort of acquiring information by the two agents under these two situations is then compared.

When the principal's preferred project is chosen, its benefit is noted $B$. In that case, the agent's expected benefit is $\beta . b$ where $\beta$ is called a parameter of congruence. Symmetrically, when the agent's preferred project is chosen, its benefit is noted $b$. In that case, the principal's expected benefit is $\alpha . B$ where $\alpha$ is the principal's parameter of congruence. $\alpha, \beta \in[0,1]$.

$E$ is the probability that the principal will acquire perfect information on the project's benefits and $(1-E)$, the probability of not learning anything. It comes at a cost $g_{P}(E)$. $E$ can be seen as a measure of the supervision exerted by the principal.

$e$ is the agent's probability of being informed about the projects' benefits and $(1-\mathrm{e})$, the probability of not getting any information over the projects.

The cost of acquiring information for the agent is noted $g_{A}(e) . e$ measures the initiative of the agent.

$E$ and $e$ represent the respective strategies of the principal and of the agent for acquiring information.

Then, in the case of integration, the agent's and principal's utilities can be written as follows

$$
\begin{aligned}
& U_{p}=E \cdot B+(1-E) \cdot e \cdot \alpha \cdot B-g_{p}(E) \\
& U_{a}=E \cdot \beta \cdot b+(1-E) \cdot e \cdot b-g_{A}(e)
\end{aligned}
$$

The principal's optimal strategy is determined by the following equation

$$
\begin{aligned}
(1-\alpha . E) \cdot e \cdot B= & g^{\prime}{ }_{P}(E) \text { and the optimal strategy } \\
& \text { of the agent by }(1-E) \cdot b=g^{\prime}{ }_{A}(e)
\end{aligned}
$$

When delegation takes place, the agent's and principal's utilities are then the following

$$
\begin{aligned}
& U_{p}^{d}=E \cdot \alpha \cdot B+(1-E) \cdot e \cdot B-g_{p}(E) \\
& U_{a}^{d}=E \cdot b+(1-E) \cdot e \cdot \beta \cdot b-g_{A}(e)
\end{aligned}
$$

In that case, the principal's optimal strategy is determined by the following equation

$$
\begin{aligned}
(1-e) \cdot B= & g^{\prime}{ }_{P}(E) \text { and the optimal strategy } \\
& \text { of the agent by }(1-\beta \cdot E) \cdot b=g^{\prime}{ }_{A}(e) .
\end{aligned}
$$

By comparing the first-order conditions in both cases, it can be shown that $E^{*}>E^{*} d$ and $e<e^{*} d$. The level of effort made by the agent under delegation is greater than that reached in the case of integration. The reverse holds for the principal. There is a trade-off between the control of the principal, which is reduced in delegation mode, and the initiative of the agent which is enhanced. 
Appendix 2. A review of existing GELOSE contracts

\begin{tabular}{|c|c|c|c|}
\hline Resource category & Location & GELOSE contracts & Operator \\
\hline Small dry forests & Sakaraha (West/South) & $\begin{array}{l}5 \text { signed GELOSE contracts } \\
\text { new contracts planned }\end{array}$ & NEO-WWF \\
\hline $\begin{array}{l}\text { Secondary or deteriorated } \\
\text { dry forests }\end{array}$ & Tulear (West/South) & $\begin{array}{l}1 \text { signed contract } \\
\text { New contracts planned }\end{array}$ & Local NGO-NEO \\
\hline Dry forests & Ejeda (West/South) & 1 signed contract & $\mathrm{NEO}$ \\
\hline Dry forests & Diego (North) & 1 signed contract & NGO \\
\hline $\begin{array}{l}\text { Dry forests } \\
\text { (fuelwood management) }\end{array}$ & Mahajanga (North) & $\begin{array}{l}5 \text { signed GELOSE contracts } \\
30 \text { contracts planned }\end{array}$ & CIRAD-FOFIFA \\
\hline Moist forest & Fort Dauphin (West/South) & $\begin{array}{l}1 \text { signed contract } \\
4 \text { planned contracts }\end{array}$ & CAF \\
\hline Moist forest & Merikanjaka (Centre) & 1 contract signed & NEO- FDP \\
\hline Tapia forest & Arivonimamo(Centre) & $\begin{array}{l}2 \text { signed GELOSE contracts } \\
9 \text { planned }\end{array}$ & NEO-FDP \\
\hline Moist forest & Ambalavoa (Centre) & $\begin{array}{l}1 \text { signed contract, } \\
\text { several planned }\end{array}$ & WWF-NEO \\
\hline $\begin{array}{l}\text { Fragments of moist } \\
\text { forests near P.A. }\end{array}$ & Andapa (East) & $\begin{array}{l}3 \text { signed GELOSE contracts, some } \\
\text { contracts signed locally, } 10 \text { planned. }\end{array}$ & NEO- WWF \\
\hline Moist forest near P.A. & Masoala (East) & Contract with lumberjacks & CARE \\
\hline Moist forests and plantations & Ambatolampy (East) & 1 contract with forestry cooperative. & PDFIV-DIREF \\
\hline Plantations & Fort Dauphin (West/South) & 1 signed contract & WWF \\
\hline $\begin{array}{l}\text { Raphia and small residual } \\
\text { moist forests. }\end{array}$ & Brickaville (East) & $\begin{array}{l}2 \text { signed GELOSE contracts on raphia } \\
1 \text { signed contract for residual forest }\end{array}$ & NEO \\
\hline Freshwater lake & Antsirabe (Centre) & Demand from the CLB & - \\
\hline
\end{tabular}

Notes: NEO: National Environmental Office, DIREF: Forestry service; WWF, CARE: NGO managers of ICDPs.

Source: Maldidier (2000) and ONE, Cellule GELOSE, Bilan des contrats, 2001. 